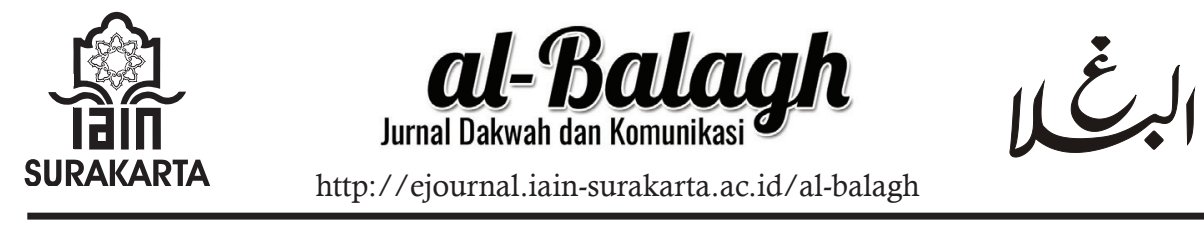

\title{
PLURALISME PEMAHAMAN KEAGAMAAN SANTRI DI SURAKARTA
}

\author{
Kamila Adnani \\ Fakultas Ushuluddin dan Dakwah IAIN Surakarta
}

\begin{tabular}{|c|c|}
\hline & Abstract \\
\hline Keywords: & Islamic boarding school (Pondok pesantren) is an effective media to \\
\hline $\begin{array}{l}\text { Pluralism of } \\
\text { religiosity, santri } \\
\text { (students of } \\
\text { Islamic Boarding } \\
\text { school) }\end{array}$ & $\begin{array}{l}\text { transform religious and cultural values. The holistic educational system } \\
\text { design of Islamic boarding school is able to internalize some important } \\
\text { values to santri (Islamic boarding school's students). The tolerance on } \\
\text { the pluralism of religiosity is an important value for the moslem young } \\
\text { generation in facing differences. The pluralism can be grown up by using }\end{array}$ \\
\hline & $\begin{array}{l}\text { The research focuses on the religious material related to pluralism in } \\
\text { understanding religion delivered by the students of PP. Al-Muayyad } \\
\text { and PP. Takmirul Islam Surakarta in their speeches when joining the } \\
\text { muhadharoh. By qualitative approach, the data analysis reveals that the } \\
\text { students of PP. Al-Muayyad and PP. Takmirul Islam Surakarta has } \\
\text { good understanding on the pluralism of religiosity. }\end{array}$ \\
\hline
\end{tabular}

\begin{abstract}
Abstrak
Pondok pesantren merupakan wadah efektif untuk transformasi nilai-nilai agama dan budaya. Desai sistem pendidikan holistik pesantren mampu menginternalisasi berbagai nilai penting pada diri santri. Toleransi atas pluralisme keberagamaan merupakan nilai yang perlu ditanamkan untuk menyiapkan generasi muda muslim toleran terhadap perbedaan. Pluralisme dapat ditanamkan dalam berbagai kegiatan pendidikan, diantaranya kegiatan muhadlaroh (latihan pidato). Penelitian ini fokus pada analisis materi-materi keagamaan bermuatan pluralisme pemahaman beragama yang disampaikan santri-santri PP Al Muayyad dan PP Takmirul Islam Surakarta dalam kegiatan latihan pidato. Dengan pendekatan kualitatif, analisis atas data yang didapatkan menyimpulkan bahwa pluralisme keagamaan santri di PP AI Muayyad Surakarta dan PPTakmirul Islam Surakarta berjalan secara baik.
\end{abstract}




\section{PENDAHULUAN}

Bangsa Indonesia merupakan bangsa yang multikulturalisme karena terdiri dari berbagai suku, ras, agama dan kebudayaan. Hal ini sesuai dengan motto Negara Indonesia yaitu Bhinneka Tunggal Ika yang artinya berbeda-beda tetapi tetap satu juga. Di Indonesia, ada bermacam-macam agama seperti Islam, Kristen, Katholik, Hindu, Budha dan Konghucu. Islam sendiri menjadi agama mayoritas masyarakat Indonesia. Oleh karena itu, seorang warga Negara Indonesia tidak boleh dipaksa dalam memilih suatu agama. Adanya hal tersebut, menimbulkan pro dan kontra terhadap pluralisme di Indonesia khususnya di bidang agama. Bila dicermati, perbedaan ini nampaknya berkaitan dengan kesalahpahaman pemaknaan pluralisme agama-budaya. Bagi yang pro pluralitas agama, keberagaman agama ini dianggap sebagai hal yang positif. Hal ini disebabkan karena keberagaman di Indonesia ini bisa menjadikan Indonesia sebagai contoh yang baik bagaimana kehidupan kerukunan antar agama.

Keberagaman ini memang harus dipertahankan dan setiap umat agama harus bisa menghormati umat agama lain. Jadi kelompok pro pluralitas beranggapan bahwa warisan sejarah dari pendiri bangsa ini harus dipertahankan. Oleh karena itu, setiap kebijakan pemerintah dalam pemerintahan haruslah menguntungkan semua umat beragama, tidak hanya menguntungkan satu umat beragama saja. Sebaliknya, bagi yang kontra terhadap pluralisme, pluralitas dianggap bisa mengancam kemurnian ajaran suatu agama. Hal ini disebabkan karena pada dasarnya setiap agama memiliki ajaran masing-masing yang berbeda dari agama lain. Kekhawatiran kelompok yang kontra pluralisme ini adalah nantinya ajaran setiap agama akan saling campur baur dengan ajaran agama lain. Selain itu, jika dilihat dari praktek di lapangan, jelas bahwa pengaplikasian toleransi masih belum dapat dilaksanakan dengan baik.

Dalam rangka membangun kerukunan hidup, khususnya dalam masyarakat yang pluralistis, terutama dari aspek agama mengenai dimensi-dimensi eksklusivisme dan inklusivisme dalam agama bisa saling 
mengenal dimensi-dimensi eksklusivitas agama selain dari agama yang dianutnya. Hal ini diharapkan dapat melahirkan sikap saling menghargai perbedaan dan bersikap toleran terhadap dimensi-dimensi eksklusivitas dalam ajaran agama lain. Hal ini dapat menekan terjadinya konflik antar umat beragama. Demikian juga dengan memahami dimensi-dimensi inklusivitas dari pihak lainnya diharapkan dapat membuahkan semangat persamaan dan persaudaraan serta persatuan (Abdurrahman 2012, 12). Dalam kehidupan masyarakat, khususnya kehidupan umat Islam, dakwah memiliki kedudukan yang sangat penting. Melalui dakwah, ajaran Islam bisa disampaikan dan dijelaskan kepada masyarakat, agar mereka menjadi tahu hal-hal yang benar maupun yang salah. Oleh karena dakwah memiliki kedudukan yang sangat penting, secara hukum dakwah menjadi kewajiban yang harus diemban oleh setiap muslim (Abidin 2012, 129).

Sejak kelahirannya 14 abad yang lalu hingga saat ini, aktivitas dakwah terus mengalami berbagai perubahan dan perkembangan. Jika dahulu dakwah Islam dilakukan secara sederhana, saat ini aktivitas dakwah dilakukan dengan menggunakan beragam metode, strategi dan media. Seiring dengan kemajuan dan dinamika masyarakat modern saat ini, dakwah pun dikemas dalam beragam bentuk dan wadah seraya memanfaatkan kemajuan dan kecanggihan alat-alat dan media komunikasi yang ada. Oleh karena itu, aktivitas dan materi dakwah bertebaran di majalah, tabloid, surat kabar, televisi, radio, film, sinetron, pertunjukan, musik dan sebagainya (Abidin 2012, 125). Salah satu metode dakwah yang dilakukan pada generasi awal umat Islam adalah metode ceramah. Metode ini menjadi salah satu karakteristik dakwah pada masa nabi dalam periode Mekkah. Namun demikian, saat ini metode ceramah mulai banyak diragukan efektivitasnya dalam menyampaikan pesan dakwah. Dakwah dengan metode ceramah dianggap sudah out of date atau konvensional. Metode ini dianggap tidak efektif seperti pertunjukan yang menuntut kelihaian pemainnya (penceramah) dalam mengolah kata, frase, kalimat serta lelucon sehingga membuat audien menangis, tertawa dan bertepuk 
tangan (Abidin 2012, 125).

Selama menimbailmu di pesantren, santri memperoleh materi-materi keagamaan dari kiai atau ustadz. Santri-santri dibekali juga ketrampilan untuk berbicara di depan publik dalam kegiatan muhadhoroh (ceramah) guna menyampaikan gagasan-gagasan tentang keagamaan. Di setiap pesantren, biasanya ada satu kegiatan yang disebut dengan mubadhoroh (public speaking) yaitu orang yang menyampaikan gagasannya di depan publik. Kegiatan mubadhoroh itu dimaksudkan untuk melatih ketrampilan para santri dalam berbicara di masyarakat. Dalam kenyataannya, materimateri keagamaan yang disampaikan oleh para santri di Pesantren dalam kegiatan semacam mubadhoroh itu kurang bermuatan pluralisme agama. Hal itu menyebabkan munculnya kelompok-kelompok pemahaman keagamaan di masyarakat Islam Generalis, Islam Tradisional, Islam Fundamentalis, Islam Liberalis dan Islam Moderat.

Peneliti tertarik untuk melihat materi-materi dakwah yang disampaikan oleh para santri di PP Al Muayyad, Surakarta dan PP Takmirul Islam, Surakarta. PP Al Muayyad, Surakarta dan PP Takmirul Islam Surakarta yang merupakan representasi dari pesantren moderat (toleran).

\section{Kelompok-kelompok Pemahaman Keagamaan dalam Islam}

Islam Liberal. Istilah Liberal tidak mudah didefinisikan, apalagi ketika istilah liberal ini melekat pada kata Islam. Masyarakat muslim memandang istilah Islam Liberal serba negatif. Nama Islam Liberal menggambarkan prinsip yang dianut yaitu Islam yang menekankan kebebasan pribadi dan pembebasan struktur politik dari dominasi yang tidak sehat dan menindas (Agung 2015, 149).

Islam Fundamentalis. Pengertian fundamentalis yang ada di dalam Kamus Besar Bahasa Indonesia adalah penganut gerakan keagamaan yang bersifat kolot dan reaksioner yang selalu merasa perlu kembali ke ajaran agama yang asli seperti yang tersurat dalam kitab suci. 
Istilah fundamentalis memiliki kesamaan dengan istilah fanatisme, Islam garis keras, ekstremisme dan radikalisme, bahkan ada yang paling menyudutkan adalah terorisme. Konsekuensi dari istilah itu tidak selalu sama, tetapi memiliki kemiripan-kemiripan karakter yaitu kekerasan, baik kekerasan pemikiran maupun kekerasan tindakan atau gerakan (Agung 2015, 145).

Islam Tradisional. Kelompok ini berasal dari Indonesia asli bukan dari luar negeri. Mereka memiliki gaya hidup layaknya santri dan memang dapat diyakini umumnya adalah orang-orang yang pernah tinggal di pondok pesantren tradisional.

Kuzman dalam Munawar Rahmat (2012) menyebutnya sebagai kelompok Islam adat. Islam adat tergolong sebagai tradisi pertama dalam Islam, yang ditandai oleh kombinasi kebiasaan-kebiasaan kedaerahan dan kebiasaan-kebiasaan yang dilakukan di seluruh dunia Islam. Kebiasaankebiasaan tradisi Islam tersebut seperti penghormatan terhadap tokohtokoh yang dianggap suci, kepercayaan suci terhadap hal-hal yang dipandang gaib dan tempat-tempat keramat seperti kuburan dan lain-lain.

Nashir dalam Munawar Rahmat (2012) menyatakan bahwa kelompok Islam tradisional di Indonesia dalam konteks gerakan awal abad ke-20 seperti kelahiran Nahdlatul Ulama

Islam Generalis. Menurut Azyumardi Azra dalam Munawar Rahmat (2012) bahwa seorang muslim yang mengamalkan ajaran Islam seadanya serta cenderung tradisional dan konvensional. Mereka melaksanakan agama sebagaimana mereka terima dari orang tua dan lingkungan mereka. Mereka mengamalkan ritual-ritual yang pokok seperti shalat dan puasa, tapi tidak begitu semangat terhadap agama.

Islam Modernis/Moderat. Menurut Quraish Shihab (2011) konsekuensi dari sikap moderat itu adalah mereka yang tidak terbawa hanyut dalam materialisme, tidak melangit sehingga tidak berpijak ke bumi. Posisi tengah menjadikan mereka mampu memadukan rohani dan jasmani, material dan spiritual dalam segala sikap dan aktivitas mereka. 
Sikap moderat mengundang umat Islam saling berinteraksi, berdialog dan terbuka dengan semua budaya, agama dan peradaban sesuai dengan perkembangan zaman.

\section{Pluralisme Pemahaman Beragama}

Menurut asal katanya, pluralism berasal dari bahasa Inggris, pluralism. Apabila meryujuk dari Wikipedia Bahasa Inggris, maka definisi pluralisme adalah In the social sciences, pluralism is a framework of interaction in which groups show sufficient respect and tolerance of each other, that they fruitfully coexist and interact without conflict or assimilation. Terjemahannya dalam bahasa Indonesia adalah suatu kerangka interaksi yang mana setiap kelompok menampilkan rasa hormat dan toleran satu sama lain, berinteraksi tanpa konflik atau asimilasi (pembauran / pembiasaan) (Wikipedia).

Adapun pengertian pluralisme agama adalah sebuah pandangan yang mendorong bahwa berbagai macam agama yang ada dalam satu masyarakat harus saling mendukung untuk bisa hidup secara damai. Pluralisme agama dapat diartikan sebagai kondisi hidup bersama (koeksistensi) antar agama (dalam arti yang luas) yang berbeda-beda dalam satu komunitas dengan tetap mempertahankan ciri-ciri spesifik atau ajaran masing-masing agama. Pluralisme agama ini sinonim untuk toleransi agama antara berbagai pemeluk agama.

\section{Metode Penelitian}

Penelitian ini menggunakan pendekatan kualitatif deskriptif. Subjek penelitiannya adalah kiai atau pengasuh PP Al Muayyad Surakarta dan PP Takmirul Islam Surakarta, pengurus atau ustadz, santri-santri yang melakukan ceramah baik di pesantren atau di masyarakat. Objek penelitiannya adalah materi-materi keagamaan yang disampaikan santrisantri dari PP Al Muayyad, Surakarta dan PP Takmirul Islam Surakarta. 


\section{HASIL PENELITIAN}

\section{Kegiatan Latihan Khitobah Santri di PP Al Muayyad Surakarta}

Latihan khitobah dilakukan oleh IPMA (Ikatan Pelajar Madrasah Al Muayyad) setiap 3 bulan sekali, dilakukan perlombaan-perlombaan antar kelas dari tingkat Madrasah Tsanawiyah, Madrasah Aliyah, SMP dan SMA. Masing-masing kelas yang diwakili 1 putra dan 1 putri melakukan latihan khitobah di depan para guru yang sekaligus menjadi juri perlombaan khitobah.

Latihan khitobah (ceramah) penting dilakukan oleh para santri di pesantren, karena beberapa faktor yaitu pertama, image masyarakat terhadap para santri itu menguasai materi-materi keagamaan termasuk dalil-dalil Al Qur'an dan Al Hadis. Kedua, melatih mental para santri untuk berbicara di depan publik, teman-temannya sesama santri dan para ustad/ guru, berani memegang mikrofon. Ketiga, para santri termotivasi dengan adanya perlombaan-perlombaan yang diselenggarakan oleh pondok pesantren maupun di luar pondok pesantren. Hal itu mendorong para santri membuat materi-materi keagamaan yang disukai oleh banyak orang dari lagu-lagu sholawatan, tampilan para dai baik di televisi, youtube, radio dan sebagainya. (Iqbal 2016)

Proses lomba khitobah yaitu mengambil perwakilan per kelas. Misalnya untuk tingkat Madrasah Aliyah dipilih 1 putra dan putri dan dari Madrasah Tsanawiyah dipilih 1 putra dan putri. Kostumnya atau pakaian yang dipakai diserahkan kepada para santri yang akan tampil. Selanjutnya ada juri dari para guru yang menilai dari materi, penampilan dan Bahasa (Iqbal2016)

Latihan khitobah santri-santri putra tingkat Madrasah Aliyah Al Muayyad Surakarta dalam rangka menyambut hari santri nasional 22 Oktober 2015 dalam rangka menyambut mensukseskan pelaksanaan Ujian Nasional (UN). Mereka melakukan ceramah keagamaan (latihan khitobah) di depan para pendamping atau gurunya dan diperlombakan. Santri-santri yang lain dapat menyaksikan pelaksanaan latihan khitobah 
santri yang dilakukan setiap 3 bulan sekali itu. Di sini nampak para santri berusaha untuk melakukan latihan khitobah dengan sebaik-baiknya. Misalnya dengan mempersiapkan sendiri materi-materi yang akan disampaikan dalam pelaksanaan latihan khitobah tersebut, mensetting tempat pelaksanaan latihan khitobah, menggunakan kostum yang sesuai dengan tema-tema yang telah disediakan oleh pengrus IPMA, melakukan gaya atau cara berbicara yang baik di depan publik (public speaking).

Para pembimbing (guru) bersemangat menjadi juri di PP Al Muayyad, Surakarta saat santri latihan khitobah. Para juri itu memberikan penilai para pembicara dari 3 aspek yaitu materi, penampilan dan bahasa yang digunakan ketika latihan khitobah. Materi maksudnya adalah pesanpesan yang diberikan oleh pembicara ketika melakukan latihan khitobah. Materi-materi (pesan-pesan) yang disampaikan oleh para pembicara sangat bervariasi misalnya tentang keutamaan sholawat, pentingnya doa dan ikhtiar, kelebihan orang yang berilmu dan sebagainya. Adapun penampilan seorang pembicara adalah semua yang tampak terlihat oleh mata audience seperti gaya, kostum, mimik, gerak tubuh (body language), intonasi suara dan sebagainya. Sedangkan Bahasa yang dimaksud adalah kata-kata yang diucapkan oleh secara lisan oleh para pembicara yang berbicara di depan podium. Apakah kata-kata atau kalimatnya disampaikan secara jelas dan benar? Biasanya Bahasa yang digunakan adalah Bahasa Indonesia.

\section{Kegiatan Latihan Khitobah di PP Takmirul Islam Surakarta}

Latihan khitobah diselenggarakan sejak awal berdirinya Pondok Pesantren Takmirul Islam (1986). Hal ini program unggulan di PP Takmirul Islam Surakarta, karena dengan itu secara tidak langsung menjadi promosi atau sosialisasi pondok pesantren Takmirul Islam (hasil wawancara peneliti dengan Bapak KH Suhardi, M.Pd tanggal 1 Juni 2016). Selama seminggu, seluruh santri PP Takmirul Islam wajib mengikuti ekstra kurikuler pramuka dan khitobah. Hal ini berarti bahwa kalau ada santri yang tidak hadir dalam kegiatan ekstra kurikuler tersebut, akan dikenai 
sanksi atau hukuman dari pengawasnya. Selain ekstra kurikuler wajib, di PP Takmirul Islam juga ada ekstra kurikuler pilihan seperti bela diri dan olah raga lainnya.

Latar belakang latihan khitobah ini dijadikan sebagai program unggulan adalah pertama, sebagian pengelola PP Takmirul Islam adalah alumni dari PP Gontor, Ponorogo sehingga mereka berusaha mentransfer ilmunya selama ini, Kedua, Santri itu dapatlah diibaratkan sebagai sebuah toko atau gudang ilmu. Kelak kalau sudah terjun ke masyarakat tentunya harus bisa menyampaikan ilmunya kepada orang lain. Bila seandainya para santri itu menjadi guru atau dosen tentunya secara otomatis dapat mentransfer ilmunya kepada orang lain, namun seandainya mereka menjadi petani dan pedagang belum tentu mempunyai kesempatan untuk menyampaikan materi-materi keagamaan kepada orang lain. Sehingga di pesantren ini merupakan wahana latihan bagi santri agar dapat mampu berbicara dengan baik di depan publik (public speaking).

Pada bulan Romadlon semua kegiatan ekstra kurikuler (khitobah, pramuka, bela diri, olah raga) diliburkan dan pada bulan Syawal akan dimulai lagi. Adapun prosesnya yaitu ada pengelompokan santri yang terdiri dari 17 kelas, terus diacak. Misalnya kelompok I terdiri dari para santri kelas 1, 2, 3 untuk mengoptimalkan latihan khitobah di Pondok Pesantren Takmirul Islam Surakarta. Latihan khitobah yang berbahasa Indonesia dilakukan setiap Kamis malam Jum'at. Latihan khitobah yang berbahasa Arab dilakukan pada hari Kamis bakda Sholat Zuhur. Latihan khitobah yang berbahasa Inggris dilakukan setiap hari Ahad malam Senin.

Ada penjadwalan rutin setiap seminggu di level ustadz, ada penanggungjawab ekstra kurikuler dibidanglatihan khitobah/muhadhoroh. Di samping itu ada mulahish (pengawas)yang bertugas membagi kelompok santri yang akan melakukan latihan khitobah/muhadhoroh. OSTI (Organisasi Santri Takmirul Islam) bagian pengajaran yang mengadakan latihan khitobah (mulai dari membagi ruangan, menentukan ketua kelompok, memilih nama-nama santri dalam satu kelompok, melabeli 
ruangan dan sebagainya). Setiap kelompok terdiri dari 30 santri. Misalnya ada kelompok A, B, C ....dan seterusnya. Setiap waktu latihan khitobah akan ditampilkan sekitar 7 santri. Setiap santri yang tampil membutuhkan waktu sekitar 7 menit. Selain itu ada santri yang mengambil intisari materi dalam latihan tersebut selama 3 menit.

Latihan khitobah santri yang berbahasa Indonesia dilakukan pada malam hari (pukul 19.00 - 22.00 WIB). Sedangkan yang mengoreksi adalah pengawas dan santri yang tampil harus dapat tanda tangan dari para pengawas. Minggu depan, akan tampil kelompok-kelompok yang lain. Selama satu setengah bulan, setiap santri akan tuntas menyelesaikan latihan khitobah dalam 3 bahasa (Arab, Inggris dan Indonesia). Materi yang akan disampaikan oleh santri disiapkan sendiri, namun tetap ada acuannya yaitu mukadimah/pembukaan, inti/isi, kesimpulan/penutup. Mukadimah biasanya berisi 1 ayat atau hadis yang akan disampaikan dalam khitobah. Sedangkan inti atau isi khitobahnya sangat beragam. Kalau berbicara mengenai prestasi santri PP Takmirul Islam Surakarta sangat banyak, misalnya Juara 4 Muhadhoroh Nasional di Medan, Juara I Puitisasi Al Qur'an Nasional. Perlombaan-perlombaan khitobah di Solo biasanya para santri PP Takmirul Islam dapat memenangkannya termasuk perlombaan yang pernah dilakukan IAIN Surakarta. Ini semua merupakan hasil dari latihan khitobah santri selama ini.

\section{Materi-materi keagamaan yang disampaikan santri dalam latihan khitobah di Pondok Pesantren Al Muayyad, Surakarta.}

Materi-materi keagamaan yang disampaikan santri dalam latihan khitobah di PP Al Muayyad, Surakarta biasanya disesuaikan dengan eventevent tertentu misalnya menjelang Ujian Nasional, Hari Santri Nasional, Pelantikan pengurus baru IPMA dan sebagainya. Temanya sangat beragam misalnya Keutamaan Doa dan ikhtiar sebagai kunci sukses dalam menghadapi Ujian Nasional, Menghormati guru, Pentingnya mencari ilmu bagi seorang santri dan sebagainya. Memang materi-materi keagamaan 
yang disampaikan santri dalam latihan khitobah itu tidak terdokumentasi yang rapi oleh pengurus, tapi sebenarnya naskah atau teks itu telah dibuat oleh santri sebelum tampil di depan audiens.

\section{Materi-materi keagamaan yang disampaikan santri dalam latihan khitobah di Pondok Pesantren Takmirul Islam, Surakarta.}

Bila dibandingkan dengan PP Al Muayyad Surakarta, materi-materi keagamaan di PP Takmirul Islam lebih tertata dengan baik. Masingmasing santri biasanya mempunyai buku tulis yang berisi tentang public speaking. Buku tersebut merupakan kumpulan materi-materikeagamaan yang disampaikan oleh setiap santri. Sebelum tampil di depan pembimbing atau ustadnya, seorang santri biasanya menuliskan materi yang akan disampaikan dalam sebuah buku. Pembimbingnya akan memberi komentar atau penilaian terhadap penampilan seorang santri. Pembimbing itu bisa memberikan komentar terhadap teks ceramahnya, bahasanya ataupun penampilannya. Adapun tema-tema yang disampaikan santri ketika latihan khitobah antara lain : Pentingnya Tawakal, Islam Memfokuskan Tauhid, dan Bahayanya Riba.

Secara sistimatika penulisan teks ceramah sudah tepat dimulai dengan salam pembukaan yaitu Assalaamu'alaikum wr. wb, Ucapan pujian kepada Allah swt, Sholawat kepada Rasululloh saw. Baru kemudian membahas pengertian riba dan bahayanya. Setelah itu membahas riba secara panjang lebar dan mengutip salah satu dalil Al-Qur'an. Hanya saja perlu mencari contoh-contoh tentang bahayanya riba bagi seorang muslim. Hal ini membuat teks ceramah ini terasa kurang lengkap. Terakhir, seorang santri perlu memberikan kesimpulan terhadap uraian yang telah disampaikan di hadapan audiens sebagai kata penutup. Hal ini untuk mengingatkan kembali memori audiens terhadap materi yang telah disampaikan oleh santri di podium. Pembimbing seharusnya memberikan penilaian yang berupa angka dan perlu memberikan komentarnya tentang teks yang telah dibuat oleh santri, bahasanya, kekurangan dan kelebihan dari isi teks itu 
sendiri.

\section{KESIMPULAN}

1. Proses latihan khitobah PP Al Muayyad Surakarta

Latihan khitobah dilakukan oleh IPMA (Ikatan Pelajar Madrasah Al Muayyad) setiap 3 bulan sekali, dilakukan perlombaan-perlombaan antar kelas dari tingkat Madrasah Tsanawiyah, Madrasah Aliyah, SMP dan SMA. Masing-masing kelas yang diwakili 1 putra dan 1 putri melakukan latihan khitobah di depan para guru yang sekaligus menjadi juri perlombaan khitobah.

2. Proses latihan khitobah PP Takmirul Islam Surakarta

Latihan khitobah diselenggarakan sejak awal berdirinya Pondok Pesantren Takmirul Islam (1986). Hal ini program unggulan di PP Takmirul Islam Surakarta, karena dengan itu secara tidak langsung menjadi promosi atau sosialisasi pondok pesantren Takmirul Islam. Selama seminggu, seluruh santri PP Takmirul Islam wajib mengikuti ekstra kurikuler pramuka dan khitobah. Hal ini berarti bahwa kalau ada santri yang tidak hadir dalam kegiatan ekstra kurikuler tersebut, akan dikenai sanksi atau hukuman dari pengawasnya. Selain ekstra kurikuler wajib, di PP Takmirul Islam juga ada ekstra kurikuler pilihan seperti bela diri dan olah raga lainnya

3. Pelaksanaan penyampaian materi keagamaan dalam latihan khitobah di PP Al Muayyad Surakarta terlihat sangat baik, karena dilakukan rutin setiap 3 bulan sekali dan dilakukan perlombaan khitobah perwakilan kelas mulai dari MTs dan MA. Selanjutnya ada juri dari para guru yang menilai dari materi, penampilan dan Bahasa.

4. Pelaksanaan penyampaian materi keagamaan dalam latihan khitobah di PP Takmirul Surakarta terlihat sangat serius dilakukan oleh para pengelola karena pelaksanaan latihan khitobah diselenggarakan seminggi sekali. Latihan khitobah yang menggunakan Bahasa Indonesia dilakukan setiap hari Kamis malam Jum'at (Pukul 19.00 - 
22.00 wib). Latihan khitobah yang berbahasa Arab dilakukan pada hari Kamis bakda Sholat Zuhur. Latihan khitobah yang berbahasa Inggris dilakukan setiap hari Ahad malam Senin.

5. Pluralisme keagamaan santri di PP Al Muayyad Surakarta dan PP Takmirul Islam Surakarta berjalan secara baik. Hal ini dapat terlihat dari materi-materi keagamaan yang disampaikan oleh santri-santri ketika latihan khitobah maupun ketika perlombaan khitobah dilakukan. Materi-materi keagamaan yang disampaikan para santri sesuai dengan Al Quran dan Al Hadis.

\section{DAFTAR PUSTAKA}

Agung, M Jiva. (2015). Renungan Bagi Aktivis Dakwah Kampus. Jakarta : PT Elex Media Komputindo Kompas Gramedia.

Abidin, Yusuf Zainal. (2013). Pengantar Retorika. Bandung : Pustaka Setia. Abdurrahman, Mustafa. (2012). Eksklusivisme dan Inklusivisme Dalam Agama Islam. Download 3 April 2016.

Bintang, Widayanto. (2014). Powerful Public Speaking. Yogyakarta: Andi.

Dewi, Fitriana Utami. (2014). Public Speaking Kunci Sukses Bicara Di Depan Publik Teori \& Praktik. Yogyakarta : Pustaka Pelajar.

Haedari.Amin . (2004). Masa Depan Pesantren Dalam Tantangan Modernitas dan Tantangan Komplesitas Global. Jakarta : IRD Press.

Madjid, Nurcholis. (1997). Bilik-bilik Pesantren Sebuab Potret Perjalanan. Jakarta : Penerbit Paramadina.

Moleong, Metodologi Penelitian Kualitatif. Bandung : PT Remaja Rosdakarya.

Mukhlish, N. (2012). Peta Gerakan Pemikiran Islam Kontemporer di Indonesia. Download 3 April 2016.

Nashir, Haedar. (2013). Islam Syariat. Bandung : Mizan.

Pancoro, Wasis. (2014). Pluralisme Agama Di Indonesia. Download tanggal 3 April 2016. 
Rahmat, Munawar. (2012). Corak Berpikir Keagamaan Mahasiswa. Bandung (Jurnal Pendidikan Agama islam Ta'lim vol. 1 no.10).

Sirait, Charles Bonar. (2013). The Power of Public Speaking : Kiat Sukses Berbicara Di Depan Publik. Jakarta : PT Gramedia Pustaka Utama.

Siradj, Said Aqil. (2015). Berkah Islam Indonesia Jalan Dakwah Rabmatan Lil 'alamin. Jakarta : PT Gramedia.

Sutopo, HB. (2006). Metodologi Penelitian Kualitatif Dasar Teori dan Terapannya dalam Penelitian. Surakarta : Universitas Sebelas Maret. 